\title{
God is Not Great, How Religion Poisons Everything
}

\section{CHRISTOPHER HITCHENS}

Quill Rating:

$\mathbf{P}$ lease accept my apologies for reviewing a well-known book by a renowned, and late, atheist almost ten years after publication. My reasons for doing so are threefold. Firstly, the book and author have both lost some of their notoriety with younger students. Secondly, the book should appeal to both to humanities and science students and will, with luck, generate conversation across disciplines. And finally, the book is brilliantly written, cleverly argued, and deserves to be read particularly after the dust of the New-Atheist movement has started (perhaps) to settle.

Christopher Hitchens was an Oxford-educated journalist with a prodigious ability to consume whiskey. He is famous for his stance on the Iraq war (he was a fervent advocate) and for his staunch anti-theism. God is Not Great is the culmination of a life-long effort to wrestle with the problem of religion. It is, perhaps, for this reason that the book reads like a series of essays united by autobiographical touches and by the author's presence which hangs on every page.

Yet the book is far more than a memoir of an atheist. It frequently challenges the reader to reflect on his own beliefs and ideas. It piques the reader's interest in a matter of history, an argument, a poem.

Hitchens' writing style is brilliant and provocative, as one quote will easily prove, '[...called] Manger Square, the centre of a tourist trap of such unrelieved tawdriness as to put Lourdes itself to shame'.

To dwell on the author's many arguments would be long-winded and rather undermine the joy of reading the book. Instead, I will consider Hitchens' most interesting and original argument; religion harms individuals and societies. Hitchens argues his point principally by historical arguments, as any good ex-Marxist would. In this way, Hitchens attempts to prove his fundamental thesis: religion is a man-made construct with which a priestly caste of people attempts to place itself in a position of real power in this world. To illustrate his point, Hitchens suggests that the fatwa against Salman Rushdie issued in 1988 by Ayatollah Khomeini was an attempt to create an issue to distract his Islamic subjects. The argument, as it stands, fails to completely convince and attempts to prove only the second part of Hitchens thesis. Yet Hitchens assures that more arguments lie in wait.

Finally, a climatic suggestion: the Maltese summer is an ideal time to read this book. What better, after a much-yearned-for, post-exam swim, than to contemplate the existence of God? 